Supporting Information

\title{
Infection Screening in Biofluids with Glucose Test Strips
}

\author{
Michael Bekhit, Hua-Yu Wang, Stanton McHardy*, and Waldemar Gorski* \\ Department of Chemistry, University of Texas at San Antonio, San Antonio, Texas 78249
}

\begin{abstract}
Included are the graphics showing a glucose test strip attached to a boxed connector (Figure S1), chronocoulometric curves obtained with the strip-potentiostat system in glucose solutions (Figure S2A) and a corresponding calibration plot (Figure S2B), dependence of chronocoulometric signal on the incubation time of LE sample with ester $\alpha$ (Figure S3), effectiveness of ester $\alpha$ vs. $\gamma$ for the determination of LE in human urine (Figure S4), and the synthesis of new glucosyl esters $\alpha, \beta, \gamma$, and $\kappa$ together with relevant NMR spectra.
\end{abstract}

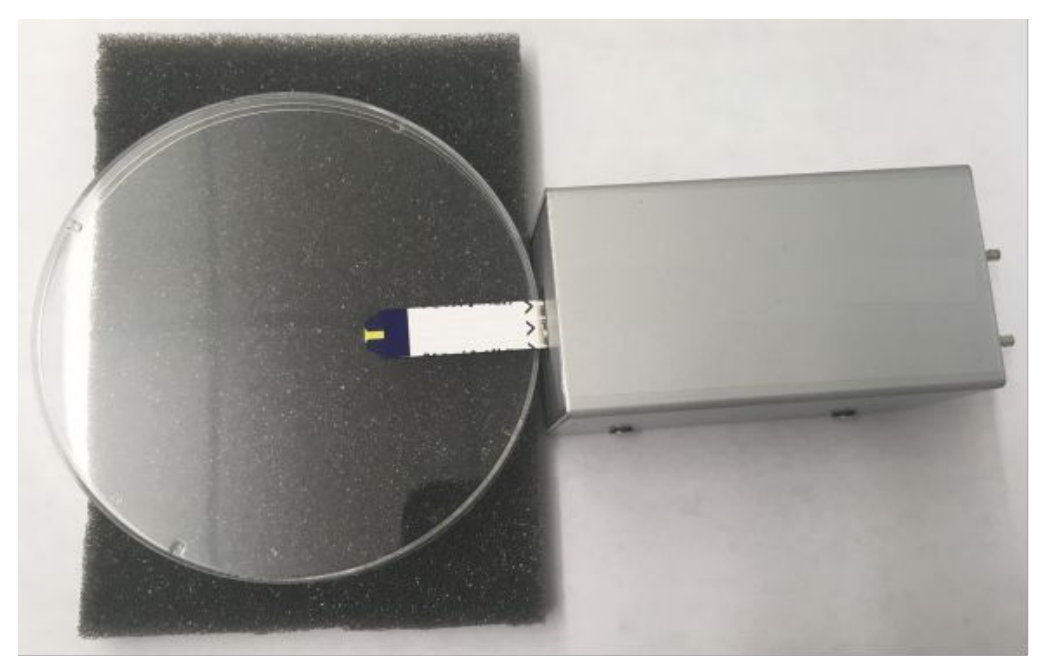

Figure S1. The ACCU CHEK glucose test strip inserted into a DropSens connector and ready to be contacted with a drop of analyzed bodily fluid placed on a Petri dish. 

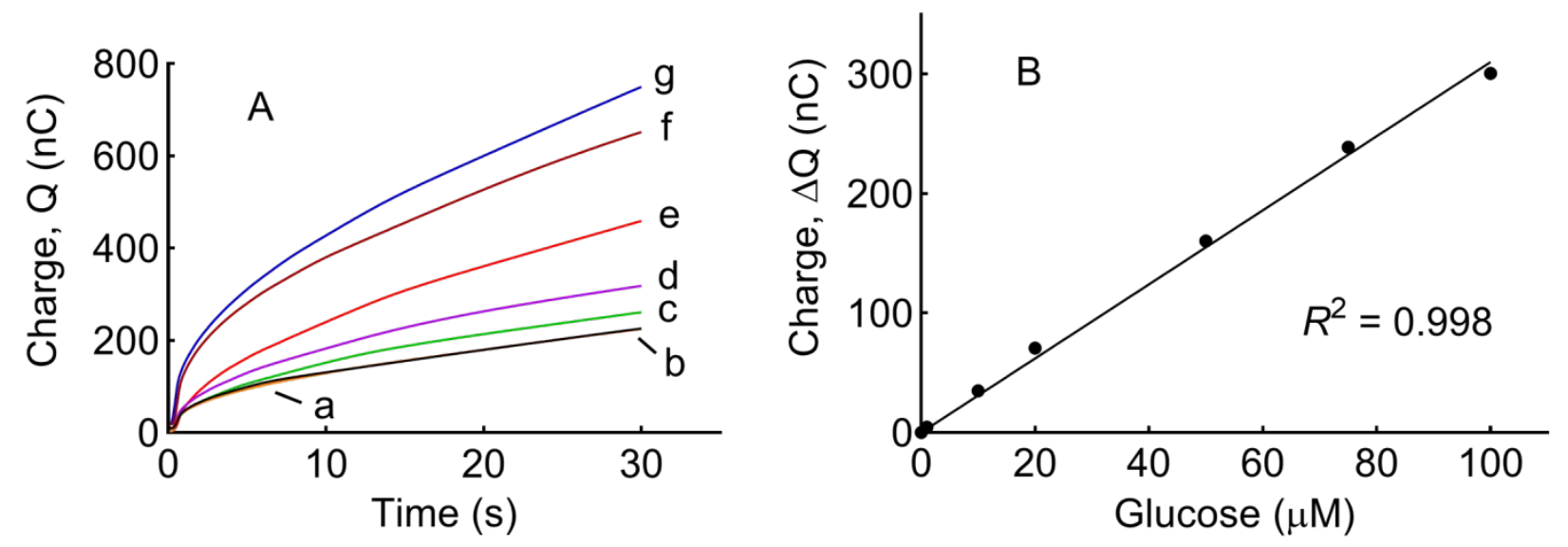

Figure S2. (A) Chronocoulometric curves obtained by the integration of chronoamperograms that were recorded with the glucose test strip-potentiostat system in $\mathrm{pH} 7.40 \mathrm{PBS}$ solutions containing (a) 0, (b) 1.0, (c) 10, (d) 20, (e) 50, (f) 75, and (g) $100 \mu \mathrm{M}$ glucose. (B) The calibration plot based on data shown in panel $\mathrm{A}$. The $\Delta \mathrm{Q}$ is a difference $\mathrm{Q}_{20 \mathrm{~s}}$ (glucose) $-\mathrm{Q}_{20 \mathrm{~s}}$ (no glucose) between the charges that were measured in the presence and absence of glucose in a solution, respectively. The values of $\mathrm{Q}_{20 \mathrm{~s}}\left(=\mathrm{Q}_{\mathrm{t}=22}-\mathrm{Q}_{\mathrm{t}=2}\right)$ were obtained by integrating the relevant amperograms for $20 \mathrm{~s}$ starting $2 \mathrm{~s}$ after contacting the sample with a strip at $\mathrm{t}=0 \mathrm{~s}$. Potential, 0.15 V vs. strip's counter/reference electrode.

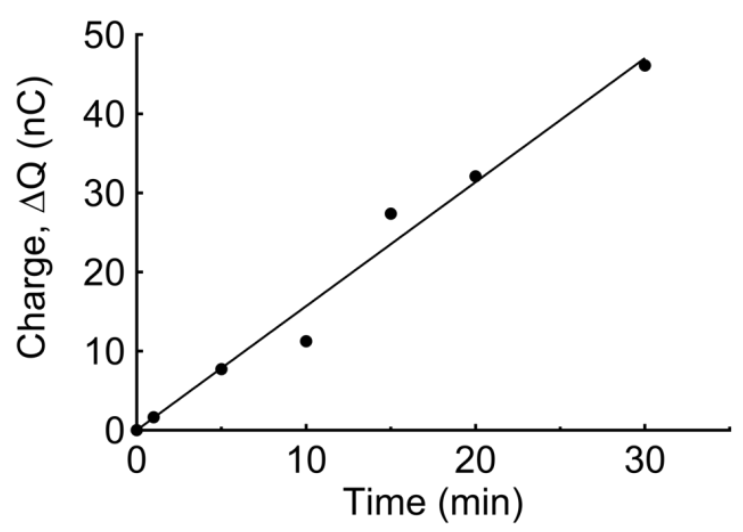

Figure S3. Dependence of $\Delta \mathrm{Q}$ on the incubation time of $25 \mu \mathrm{g} \mathrm{L}^{-1} \mathrm{LE}$ solution ( $\mathrm{pH} 7.40 \mathrm{PBS}$ ) with $5.5 \mathrm{mM}$ ester $\alpha$. The $\Delta \mathrm{Q}$ is a difference $\mathrm{Q}_{20 \mathrm{~s}}$ (incubated) $-\mathrm{Q}_{20 \mathrm{~s}}$ (original) between the charges that were measured in an ester-incubated and original sample, respectively. The values of $\mathrm{Q}_{20 \mathrm{~s}}\left(=\mathrm{Q}_{\mathrm{t}=22}-\mathrm{Q}_{\mathrm{t}=2}\right)$ were obtained by integrating the relevant amperograms for $20 \mathrm{~s}$ starting 2 $\mathrm{s}$ after contacting the sample with a strip. Potential, $0.15 \mathrm{~V}$ vs. glucose strip's counter/reference electrode. 


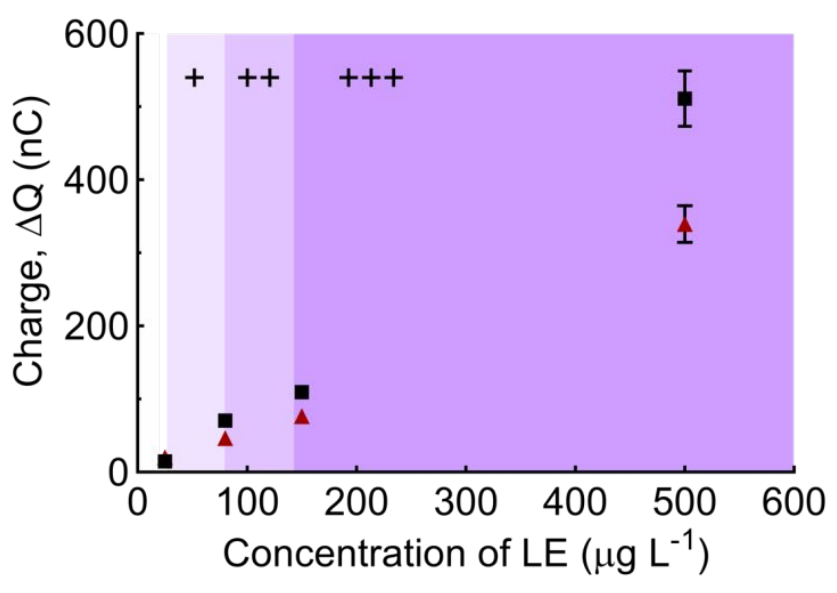

Figure S4. Chronocoulometric charge $\Delta \mathrm{Q}$ vs. the concentration of LE in human urine samples incubated for 5 min with ester $\alpha$ (black squares) and 10 min with ester $\gamma$ (red triangles). Ester concentration, $5.5 \mathrm{mM}$. The $\Delta \mathrm{Q}$ is a difference $\mathrm{Q}_{20 \mathrm{~s}}$ (incubated) $-\mathrm{Q}_{20 \mathrm{~s}}$ (original) between the charges that were measured in an ester-incubated and original sample, respectively. The values of $\mathrm{Q}_{20 \mathrm{~s}}\left(=\mathrm{Q}_{\mathrm{t}=22}-\mathrm{Q}_{\mathrm{t}=2}\right)$ were obtained by integrating the relevant amperograms for $20 \mathrm{~s}$ starting 2 $s$ after contacting the sample with a glucose test strip. The error bars $( \pm \mathrm{SD})$ for points at $<100$ $\mu \mathrm{g} \mathrm{L}{ }^{-1} \mathrm{LE}$ were smaller than markers. The different intensities of purple show a response of commercial colorimetric LE test strips to increasing concentration of LE (from trace to,+++ , +++ ). Potential, 0.15 V vs. strip's counter/reference electrode.

\section{Synthesis of Glucosyl Esters}

The air- and moisture-sensitive reactions were performed under nitrogen atmosphere by using dry solvents and glassware under anhydrous conditions. The starting materials and reagents were the commercial compounds of the highest purity available and were used without purification. The solvents were of commercial dry, extra-dry or analytical grade. The analytical thin layer chromatography was performed on aluminum plates coated with Merck Kieselgel 60F254 and visualized by UV irradiation $(254 \mathrm{~nm})$ or by staining with a solution of potassium permanganate. Flash column chromatography was performed on Biotage Isolera One 2.2 using commercial columns that were pre-packed with Merck Kieselgel 60 (230 400 mesh) silica gel. The final compounds were all $\geq 95 \%$ purity as determined by HPLC-MS and 'H NMR.

NMR spectra were recorded on Agilent DD2 400MHz spectrometer at ambient temperature. Samples were dissolved and prepared in deuterated solvents $\left(\mathrm{CDCl}_{3}, \mathrm{CD}_{3} \mathrm{OD}\right.$ and $\mathrm{DMSOd}_{6}$ ) with residual solvents being used as the internal standard in all cases. All deuterated solvent peaks were corrected to the standard chemical shifts $\left(\mathrm{CDCl}_{3}, d_{\mathrm{H}}=7.26 \mathrm{ppm}\right.$; $\left.\mathrm{CD}_{3} \mathrm{OD}, d_{\mathrm{H}}=3.31 \mathrm{ppm} ; \mathrm{DMSO}-d_{6}, d_{\mathrm{H}}=2.50 \mathrm{ppm}\right)$. Spectra were all manually integrated after automatic baseline correction. Chemical shifts $(d)$ are given in parts per million (ppm), and coupling constants $(J)$ are given in Hertz $(\mathrm{Hz})$. The proton spectra are reported as follows: d 
(multiplicity, coupling constant $J$, number of protons). The following abbreviations were used to explain the multiplicities: $a p p=$ apparent, $\mathrm{b}=$ broad, $\mathrm{d}=$ doublet, $\mathrm{dd}=$ doublet of doublets, $\mathrm{ddd}=$ doublet of doublet of doublets, dddd $=$ doublet of doublet of doublet of doublets, $\mathrm{m}=$ multiplet, $\mathrm{s}$ $=$ singlet, $\mathrm{t}=$ triplet.

HPLC-MS low-resolution mass spectra (EI) of all samples were recorded on platform-1: Agilent 1290 series HPLC system (Method 1) comprised of binary pumps, degasser and UV detector, equipped with an auto-sampler that was coupled with Agilent 6150 mass spectrometer; platform-2: Thermo Scientific Vanquish UHPLC system. The general Liquid Chromatography parameters were as follows using solvent A $(0.10 \%$ formic acid in water) and solvent $\mathrm{B}(0.00 \%$ formic acid in acetonitrile): Method-1: analysis was performed on a Zorbax Eclipse Plus C18 column with dimension of $2.1 \times 50 \mathrm{~mm}$. The flow rate was $0.7 \mathrm{~mL} \mathrm{~min}^{-1}$ running a gradient of $5 \%$ to $95 \%$ solvent B in 5 minutes and hold at $95 \%$ solvent B for 2 minutes. Method-2: analysis was performed on a Hypersil GOLD C18 column with dimension of 2.1x100 mm. The flow rate was $1.0 \mathrm{~mL} \mathrm{~min}^{-1}$ running a gradient of $5 \%$ to $95 \%$ solvent $\mathrm{B}$ in 0.8 minutes and hold at $95 \%$ solvent B for 0.4 minutes. The atmospheric pressure electrospray in the positive ion mode with a fragmentation voltage of 50 volts was used.

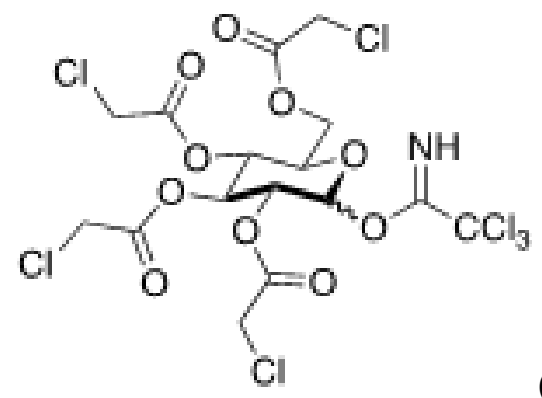

(2R,3R,4S,5R)-2-((2-chloroacetoxy)methyl)-6-(2,2,2-trichloro1-iminoethoxy)tetrahydro-2H-pyran-3,4,5-triyl tris(2-chloroacetate) 3: The glucosyl donor 3 was prepared in three steps according to the literature procedure. ${ }^{1}$ Preparation of 2,3,4,6-tetra- $\boldsymbol{O}$-chloroacetylglucose 2: The solution of $\beta$-D-glucose $(5.0 \mathrm{~g}, 27.7 \mathrm{mmol}$, 1 equiv) in dry $\mathrm{CH}_{2} \mathrm{Cl}_{2}(110 \mathrm{ml})$ and dry pyridine $(14 \mathrm{ml})$ at $0^{\circ} \mathrm{C}$ was added to a solution of chloroacetyl chloride (31.3 g, $277 \mathrm{~mol}, 10$ equiv) in dry $\mathrm{CH}_{2} \mathrm{Cl}_{2}(45 \mathrm{ml})$ through an addition funnel over a period of $2 \mathrm{~h}$. The resulting slurry turned from bright orange/red color to a yellowish homogeneous solution after stirring at room temperate for $24 \mathrm{~h}$. The reaction mixture was quenched with $1 \mathrm{M} \mathrm{HCl}$ aqueous solution $(100 \mathrm{ml})$ and the mixture was extracted with $\mathrm{CH}_{2} \mathrm{Cl}_{2}(2 \times 50 \mathrm{ml})$. The combined organic extracts were washed with saturated $\mathrm{NaHCO}_{3}$ (aq.) $(100 \mathrm{ml})$, brine $(100 \mathrm{ml})$, dried over $\mathrm{Na}_{2} \mathrm{SO}_{4}$, filtered and concentrated under reduced pressure. The crude material was purified by Biotage flash chromatography (gradient elution, 0 to $35 \%$ EtOAc in hexanes) to obtain penta(chloroacetyl)-glucose (15.2 g, 98\%) as viscous yellow oil. The solution of penta(chloroacetyl)-glucose (1.3 g, $2.31 \mathrm{mmol}, 1$ equiv) in $\operatorname{DMF}(4 \mathrm{~mL})$ at $0^{\circ} \mathrm{C}$ was added to hydrazine acetate $(255 \mathrm{mg}, 2.77 \mathrm{mmol}, 1.2$ equiv). The reaction mixture was stirred at this temperature for $2 \mathrm{~h}$. Upon reaction completion confirmed by TLC analysis (50\% EtOAc in hexanes), the solution was diluted with EtOAc $(20 \mathrm{~mL})$, washed 
with $\mathrm{H}_{2} \mathrm{O}(20 \mathrm{~mL})$, the organic extracts washed with brine, dried over $\mathrm{Na}_{2} \mathrm{SO}_{4}$, and filtered and concentrated under reduced pressure. The crude material was purified by Biotage flash chromatography (gradient elution, 0 to $35 \%$ EtOAc in hexanes) to yield compound 2 (883 $\mathrm{mg}$, 79\%) as a colorless foam. Preparation of glucosyl donor 3: The solution of the 2,3,4,6-tetra$O$-chloroacetylglucose (2) (1.82 g, $3.74 \mathrm{mmol}, 1$ equiv) in dry $\mathrm{CH}_{2} \mathrm{Cl}_{2}(12 \mathrm{~mL})$ at $0^{\circ} \mathrm{C}$ was added to a stirred trichloroacetonitrile $(5.4 \mathrm{~g}, 37.4 \mathrm{mmol}, 10$ equiv) containing a catalytic amount of DBU ( $85 \mathrm{mg}, 0.561 \mathrm{mmol}, 0.15$ equiv) and allowed to gradually warm to room temperature overnight. The reaction mixture was concentrated and the resulting residue was purified by Biotage flash chromatography (gradient elution, 0 to $20 \%$ EtOAc in hexanes) to yield the compound 4 (2.06 g, 88\%) as a yellow viscous oil.

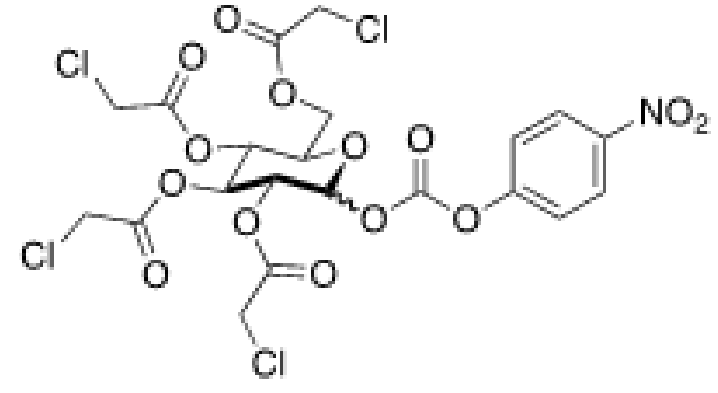

$(2 R, 3 R, 4 S, 5 R)-2-((2-c h l o r o a c e t o x y) m e t h y l)-6-(((4-$ nitrophenoxy)carbonyl)oxy)tetrahydro-2H-pyran-3,4,5-triyl tris(2-chloroacetate) 4: The solution of 2,3,4,6-tetra-O-chloroacetylglucose (2) (1.1 g, $2.26 \mathrm{mmol}, 1$ equiv) in dry $\mathrm{CH}_{2} \mathrm{Cl}_{2}(12$ $\mathrm{mL}$ ) at $0^{\circ} \mathrm{C}$ was added to triethylamine (343 $\mathrm{mg}, 3.39 \mathrm{mmol}, 1.5$ equiv) and 4-nitrophenyl chloroformate (547 mg, $2.71 \mathrm{mmol}, 1.2$ equiv) and stirred for $1 \mathrm{~h}$ at room temperature. The reaction mixture was concentrated and the resulting residue was purified by Biotage flash chromatography (gradient elution, 0 to $35 \%$ EtOAc in hexanes) to yield the title compound 5 (1.2 g, 81\%) as a yellow viscous oil.<smiles>C[C@H](N)C(=O)OCCNC(=O)OCc1ccccc1</smiles>

\section{NHTs Representative procedure of Steglish esterification to} prepare ester intermediates for compounds 7a-d. Preparation of 2-((tertbutoxycarbonyl)amino)ethyl tosyl- $L$-alaninate: The solution of tosyl-Lalanie 5 (1.58 g, $6.51 \mathrm{mmol}, 1.05$ equiv) and N-boc-glycinol 6a $(\mathrm{R}=\mathrm{H})(1 \mathrm{~g}, 6.20 \mathrm{mmol}$, 1 equiv) in dry $\mathrm{CH}_{2} \mathrm{Cl}_{2}(15 \mathrm{ml})$ was added to DMAP (380 mg, $3.10 \mathrm{mmol}, 0.5$ equiv) and EDCI ( $1.30 \mathrm{~g}, 6.82 \mathrm{mmol}, 1.1$ equiv) and the resulting mixture was stirred at room temperature for 24 h. The solution was concentrated and purified by Biotage flash chromatography (gradient elution, 0 to $40 \%$ EtOAc in hexanes) to yield the coupled intermediate $(\mathrm{R}=\mathrm{H})(1.61 \mathrm{~g}, 64 \%)$ as a colorless oil. ' ${ }^{H} \mathrm{NMR}(400 \mathrm{MHz}$, Chloroform-d) $\delta 7.74(\mathrm{~d}, J=8.2 \mathrm{~Hz}, 2 \mathrm{H}), 7.30(\mathrm{~d}, J=8.2$ Hz, 2H), 5.21 (m, 1H), 4.69 (br, 1H), $4.04-3.95$ (m, 3H), 3.27 (m, 2H), 2.42 (s, 3H), 1.45 (s, 9H), 1.38 (d, $J=7.2 \mathrm{~Hz}, 3 \mathrm{H}$ ). LCMS (m/z) 287.2 (M-Boc); RT (Method 2, std LCMS method), $1.25 \mathrm{~min}$. 
<smiles>C[C@H]([NH3+])C(=O)OCCN(C)C(=O)OC(C)(C)C</smiles>

Preparation of 2-((tert-butoxycarbonyl)(methyl)amino)ethyl tosyl-

$\boldsymbol{L}$-alaninate: The coupled intermediate $\left(\mathrm{R}=\mathrm{CH}_{3}\right)$ was prepared by using the reaction conditions described above and the corresponding N-methyl-N-boc-glycinol $6 \mathbf{b}$ ( $1 \mathrm{~g}, 5.70 \mathrm{mmol}, 1$ equiv $)$ to yield the coupled intermediate $\left(\mathrm{R}=\mathrm{CH}_{3}\right)(1.40 \mathrm{~g}, 58 \%)$ as a colorless oil. ${ }^{1} \mathrm{H}$ NMR (400 MHz, Chloroform-d) $\delta 7.73$ (d, $J=8.3 \mathrm{~Hz}, 2 \mathrm{H}), 7.29$ (d, $J=8.2 \mathrm{~Hz}, 2 \mathrm{H}), 4.04$ (m, 2H), 3.97 (pent, $J=$ $7.8 \mathrm{~Hz}, 1 \mathrm{H}), 3.44-3.29$ (br, 3H). 2.83 (s, 3H), 2.42 (s, 3H), 1.45 (s, 9H), 1.39 (d, J= $7.2 \mathrm{~Hz}$, 3H). LCMS (m/z) 301.1 (M-Boc); RT (Method 2, std LCMS method), $1.08 \mathrm{~min}$.<smiles>CCCCC(=O)OCCCOC(=O)[C@H](C)N</smiles>

Preparation of tert-butyl 4-((tosyl- $\boldsymbol{L}$-alanyl)oxy)butanoate: The coupled intermediate $(\mathrm{R}=\mathrm{H})$ was prepared by using the reaction conditions described above and the corresponding tert-butyl 4-hydroxybutanoate 6c (2.64 g, $16.47 \mathrm{mmol}, 1$ equiv) to yield the coupled intermediate ( $\mathrm{R}$ $=\mathrm{H})(5.71 \mathrm{~g}, 91 \%)$ as a colorless oil. ${ }^{1} \mathrm{H}$ NMR $(400 \mathrm{MHz}$, Chloroform-d) $\delta 7.72(\mathrm{~d}, J=8.2 \mathrm{~Hz}$, 2H), $7.30(\mathrm{~d}, J=8.0 \mathrm{~Hz}, 2 \mathrm{H}), 5.19(\mathrm{~d}, J=8.2 \mathrm{~Hz}, 1 \mathrm{H}), 4.01-3.92(\mathrm{~m}, 3 \mathrm{H}), 2.42(\mathrm{~s}, 3 \mathrm{H}), 2.20$ (t, $J=7.4 \mathrm{~Hz}, 2 \mathrm{H}), 1.80$ (pent, $J=7.2 \mathrm{~Hz}, 2 \mathrm{H}), 1.45$ (s, 9H), 1.39 (d, $J=7.2 \mathrm{~Hz}, 3 \mathrm{H}$ ).<smiles>CCCCC(C)(C)C(=O)OCCC(C)(C)[C@@H](C)N</smiles>

alanyl)oxy)butanoate: The coupled intermediate $\left(\mathrm{R}=\mathrm{CH}_{3}\right)$ was prepared by using the reaction conditions described above and the corresponding tert-butyl-4-hydroxy-2,2dimethylbutanoate $\mathbf{6 d}$ (746 mg, $3.96 \mathrm{mmol}, 1$ equiv) to yield the coupled intermediate $\left(\mathrm{R}=\mathrm{CH}_{3}\right)$ $(1.11 \mathrm{~g}, 68 \%)$ as a colorless oil. ' $\mathrm{H}$ NMR (400 MHz, Chloroform-d) $\delta 7.72(\mathrm{~d}, J=8.2 \mathrm{~Hz}, 2 \mathrm{H})$, $7.29(\mathrm{~d}, J=8.2 \mathrm{~Hz}, 2 \mathrm{H}), 5.18(\mathrm{~m}, 1 \mathrm{H}), 3.95(\mathrm{~m}, 3 \mathrm{H}), 2.41(\mathrm{~s}, 3 \mathrm{H}), 1.70(\mathrm{~m}, 2 \mathrm{H}), 1.43(\mathrm{~s}, 9 \mathrm{H})$, $1.37(\mathrm{~d}, J=7.1 \mathrm{~Hz}, 3 \mathrm{H}), 1.11(\mathrm{~s}, 6 \mathrm{H})$.<smiles>C[C@H](N)C(=O)OCCN</smiles>

Representative procedure of acidic deprotection of tert-butylcarbamate using HCl to prepare compounds $7 \mathrm{a}$ and $7 \mathrm{~b}$. Preparation of 2 -aminoethyl tosyl$\boldsymbol{L}$-alaninate hydrochloride salt 7a: The solution of the corresponding intermediate described above ( $1.61 \mathrm{~g}, 4.16 \mathrm{mmol}, 1$ equiv) in dry $\mathrm{CH}_{2} \mathrm{Cl}_{2}(15 \mathrm{ml})$ was added to $4 \mathrm{M} \mathrm{HCl}$ solution in dioxane $(5.2 \mathrm{~mL}, 20.8 \mathrm{mmol}, 5$ equiv $)$, and the resulting mixture was stirred at room temperature for $3 \mathrm{~h}$. The solution was concentrated and triturated with methanol and diethyl ether, and the precipitate was filtered and washed with diethyl ether to yield 
compound 7a $(\mathrm{R}=\mathrm{H})$ as a hydrochloride salt $(1.30 \mathrm{~g}, 97 \%)$. ${ }^{1} \mathrm{H}$ NMR (400 MHz, DMSO-d6) $\delta$ $8.28(\mathrm{br}, 4 \mathrm{H}), 7.68(\mathrm{~d}, J=8.0 \mathrm{~Hz}, 2 \mathrm{H}), 7.39(\mathrm{~d}, J=8.1 \mathrm{~Hz}, 2 \mathrm{H}), 4.05(\mathrm{~m}, 1 \mathrm{H}), 3.94(\mathrm{~m}, 2 \mathrm{H}), 2.94$ (m, 2H), $2.38(\mathrm{~s}, 3 \mathrm{H}), 1.21(\mathrm{~d}, J=7.2 \mathrm{~Hz}, 3 \mathrm{H})$. LCMS (m/z) 287.1 (M+1); RT (Method 2, std LCMS method), $0.74 \mathrm{~min}$.

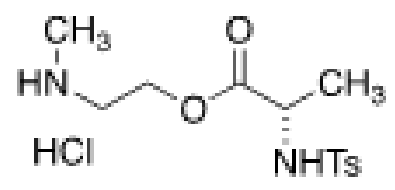

Preparation of 2-(methylamino)ethyl tosyl-L-alaninate $7 \mathbf{b}: 7 \mathbf{b}\left(\mathrm{R}=\mathrm{CH}_{3}\right)$ was prepared by using the reaction conditions described above and the corresponding intermediate described above (1.40 g, $3.49 \mathrm{mmol}, 1$ equiv) to yield compound $7 \mathbf{b}\left(\mathrm{R}=\mathrm{CH}_{3}\right)$ as a hydrochloride salt (1.08 g, 92\%). 'H NMR (400 MHz, DMSO-d6) $\delta 8.86(\mathrm{br}, 2 \mathrm{H}), 8.28(\mathrm{br}, 1 \mathrm{H}), 7.67$ (d, $J=$ $8.2 \mathrm{~Hz}, 2 \mathrm{H}), 7.40(\mathrm{~d}, J=8.0 \mathrm{~Hz}, 2 \mathrm{H}), 4.11(\mathrm{~m}, 1 \mathrm{H}), 4.02(\mathrm{~m}, 1 \mathrm{H}), 3.92(\mathrm{~m}, 1 \mathrm{H}), 3.07(\mathrm{~m}, 2 \mathrm{H})$, $2.56(\mathrm{~s}, 3 \mathrm{H}), 2.39(\mathrm{~s}, 3 \mathrm{H}), 1.20(\mathrm{~d}, J=7.2 \mathrm{~Hz}, 3 \mathrm{H})$. LCMS (m/z) $301.2(\mathrm{M}+1)$; RT (Method 2, std LCMS method), 0.73 min.<smiles>CC(N)C(=O)OCCCC(=O)O</smiles>
ester using TFA to prepare compounds $7 \mathrm{c}$ and $7 \mathrm{~d}$ : Preparation of 4-((tosyl- $L$ alanyl)oxy)butanoic acid 7c: The solution of the corresponding intermediate described above (4.64 g, $12.0 \mathrm{mmol}, 1$ equiv) in $\mathrm{CH}_{2} \mathrm{Cl}_{2} 40 \mathrm{ml}$ ) was added to TFA $/ \mathrm{CH}_{2} \mathrm{Cl}_{2}$ (v:v/1:1, $40 \mathrm{~mL}$ ) at $0^{\circ} \mathrm{C}$ and stirred for $3 \mathrm{~h}$ at room temperature. The solution was concentrated and purified by Biotage flash chromatography (gradient elution, 0 to $75 \%$ EtOAc in hexanes) to yield compound $7 \mathbf{c}(\mathrm{R}=\mathrm{H})(3.45 \mathrm{~g}, 87 \%)$ as a colorless gel. ${ }^{1} \mathrm{H}$ NMR (400 MHz, Chloroform-d) $\delta 7.74(\mathrm{~d}, J=8.2 \mathrm{~Hz}, 2 \mathrm{H}), 7.30(\mathrm{~d}, J=8.4 \mathrm{~Hz}, 2 \mathrm{H}), 5.35(\mathrm{br}, 1 \mathrm{H}), 5.28(\mathrm{~d}, J=8.6 \mathrm{~Hz}, 1 \mathrm{H}), 4.05$ -3.95 (m, 3H), 2.42 (s, 3H), 2.37 (t, $J=7.2 \mathrm{~Hz}, 2 \mathrm{H}), 1.94-1.84$ (m, 2H), 1.37 (d, $J=7.2 \mathrm{~Hz}$, 3H). LCMS (m/z) 330.1 (M+1); RT (Method 2, std LCMS method), $1.02 \mathrm{~min}$.<smiles>CC(N)C(=O)OCCC(C)(C)C(=O)O</smiles>

Preparation of 2,2-dimethyl-4-((tosyl- $L$-alanyl)oxy)butanoic

acid $7 \mathbf{d}: 7 \mathbf{d}\left(\mathrm{R}=\mathrm{CH}_{3}\right)$ was prepared by using the reaction conditions described above and the corresponding intermediate described above $(1.11 \mathrm{~g}, 2.68 \mathrm{mmol}, 1$ equiv) to yield compound $7 \mathbf{d}\left(\mathrm{R}=\mathrm{CH}_{3}\right)(930 \mathrm{mg}, 97 \%)$ as a colorless gel. ' $\mathrm{H}$ NMR (400 $\mathrm{MHz}$, Chloroform-d) $\delta 7.74$ (d, $J=8.2 \mathrm{~Hz}, 2 \mathrm{H}), 7.30$ (d, $J=8.1 \mathrm{~Hz}, 2 \mathrm{H}), 5.38$ (d, $J=8.8 \mathrm{~Hz}, 1 \mathrm{H}), 4.09$ $-3.96(\mathrm{~m}, 3 \mathrm{H}), 2.42$ (s, 3H), $1.96-1.82(\mathrm{~m}, 2 \mathrm{H}), 1.32$ (d, $J=7.2 \mathrm{~Hz}, 3 \mathrm{H}), 1.24$ (s, 3H), 1.21 (d, 3H). LCMS (m/z) 358.1 (M+1); RT (Method 2, std LCMS method), $1.15 \mathrm{~min}$. 


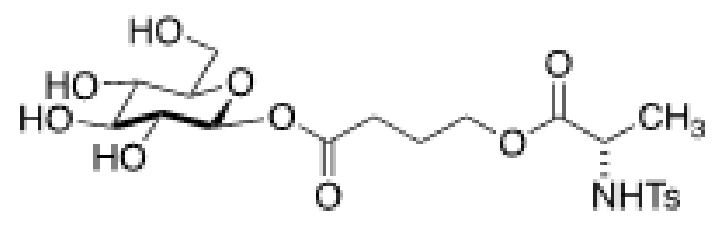

\section{Representative procedure of glucosylation using}

glucosyl donor 3. Preparation of compound 8a (ester $\alpha$ ): The flame-dried round-bottom flask with activated $4 \AA$ molecular sieves was charged with compounds 3 ( $478 \mathrm{mg}, 0.75 \mathrm{mmol}$, 1 equiv) and $7 \mathbf{c}\left(275 \mathrm{mg}, 0.84 \mathrm{mmol}, 1.1\right.$ equiv) and dry $\mathrm{CH}_{2} \mathrm{Cl}_{2}(7.5 \mathrm{ml})$. The mixture was cooled to $0^{\circ} \mathrm{C}$, TMSOTf ( $34 \mathrm{mg}, 0.15 \mathrm{mmol}, 0.2$ equiv) was added, and the solution was stirred for $24 \mathrm{~h}$ allowing it to slowly warm to room temperature. The reaction was quenched by adding a saturated aqueous solution of $\mathrm{NaHCO}_{3}(20 \mathrm{~mL})$ and solution extracted with $\mathrm{CH}_{2} \mathrm{Cl}_{2}(2 \times 20 \mathrm{~mL})$. The combined organic extracts were dried over $\mathrm{Na}_{2} \mathrm{SO}_{4}$, and filtered and concentrated under the reduced pressure. The crude material was diluted with pyridine/water (v:v/1:1, $8 \mathrm{~mL}$ ), and the reaction mixture was stirred at room temperature for $48 \mathrm{~h}$ until all the chloroacetyl groups was removed based on HPLC/MS analysis. The solution was concentrated by azeotropically removing the residual water with toluene under reduced pressure, and the material was purified by Biotage flash chromatography (gradient elution, 0 to $25 \% \mathrm{MeOH}$ in $\mathrm{CH}_{2} \mathrm{Cl}_{2}$ ) to yield compound $\mathbf{8 a}$ (ester $\left.\boldsymbol{\alpha}\right)(126 \mathrm{mg}, 35 \%$ over two steps) as colorless foam. ' $\mathrm{H}$ NMR (400 MHz, Methanol-d4) $\delta 7.71(\mathrm{~d}, J=8.2 \mathrm{~Hz}, 2 \mathrm{H}), 7.37$ (d, $J=8.1 \mathrm{~Hz}, 2 \mathrm{H}), 5.49$ (d, $J=$ $8.2 \mathrm{~Hz}, 1 \mathrm{H}), 3.98-3.82(\mathrm{~m}, 4 \mathrm{H}), 3.68(\mathrm{dd}, J=12.0,4.9 \mathrm{~Hz}, 1 \mathrm{H}), 3.45-3.35(\mathrm{~m}, 4 \mathrm{H}), 2.42$ (s, $3 \mathrm{H}), 2.43-2.37(\mathrm{~m}, 2 \mathrm{H}), 1.81$ (pent, $J=6.9 \mathrm{~Hz}, 2 \mathrm{H}), 1.29$ (d, $J=7.2 \mathrm{~Hz}, 3 \mathrm{H})$. LCMS (m/z) 490.8 (M-1); RT (Method 2, std LCMS method), 0.85 min.

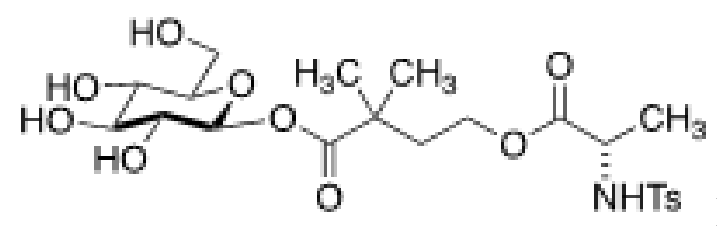

(ester $\beta$ ): $\mathbf{8 b}$ (ester $\beta$ ) was prepared by using the reaction conditions described above and the corresponding acid 7d (440 mg, $1.23 \mathrm{mmol}, 1.1$ equiv). The crude material after the final removal of all the chloroacetyl groups was purified by Biotage flash chromatography (gradient elution, 0 to $18 \% \mathrm{MeOH}$ in $\mathrm{CH}_{2} \mathrm{Cl}_{2}$ ) to yield compound $\mathbf{8 b}$ (ester $\boldsymbol{\beta}$ ) (327 $\mathrm{mg}$, $56 \%$ over two steps) as a colorless foam. 'H NMR (400 MHz, Methanol-d4) $\delta 7.72(\mathrm{~d}, J=8.3 \mathrm{~Hz}, 2 \mathrm{H}), 7.36$ $(\mathrm{d}, J=8.0 \mathrm{~Hz}, 2 \mathrm{H}), 5.45(\mathrm{~d}, J=8.0 \mathrm{~Hz}, 1 \mathrm{H}), 4.00-3.78(\mathrm{~m}, 4 \mathrm{H}), 3.76-3.64(\mathrm{~m}, 1 \mathrm{H}), 3.45-$ $3.34(\mathrm{~m}, 4 \mathrm{H}), 2.43(\mathrm{~s}, 3 \mathrm{H}), 1.86-1.71(\mathrm{~m}, 2 \mathrm{H}), 1.27(\mathrm{~d}, J=7.2 \mathrm{~Hz}, 3 \mathrm{H}), 1.21(\mathrm{~s}, 3 \mathrm{H}), 1.20(\mathrm{~s}$, 3H). LCMS (m/z) 518.8 (M-1); RT (Method 2, std LCMS method), $0.92 \mathrm{~min}$.

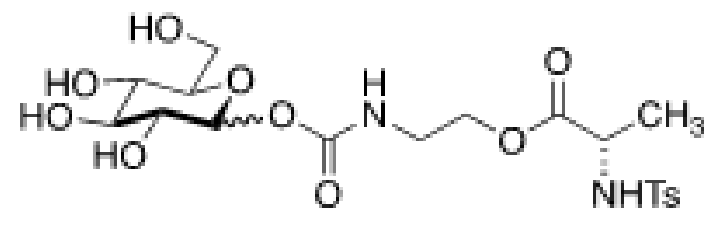

Representative procedure of glucosylation using glucosyl donor 4. Preparation of compound 9a (ester $\gamma$ ): To a solution of 4 (480 mg, 0.73 
mmol, 1 equiv) and $7 \mathbf{a}\left(238 \mathrm{mg}, 0.73 \mathrm{mmol}, 1\right.$ equiv) in dry $\mathrm{CH}_{2} \mathrm{Cl}_{2}(5 \mathrm{ml})$, the DIPEA (188 $\mathrm{mg}$, $1.46 \mathrm{mmol}, 2$ equiv) was added and the resulting mixture was stirred at room temperature for 24 $\mathrm{h}$. The solution was concentrated under reduced pressure, the pyridine/water $(\mathrm{v}: \mathrm{v} / 1: 1,10 \mathrm{~mL})$ solvent was added, and the mixture was stirred at room temperature for $48 \mathrm{~h}$ until all of the chloroacetyl groups were removed based on HPLC/MS analysis. The solution was concentrated by azeotropically removing the residual water with toluene under reduced pressure, and the material was purified by Biotage flash chromatography (gradient elution, 0 to $25 \%$ $\mathrm{MeOH}$ in $\left.\mathrm{CH}_{2} \mathrm{Cl}_{2}\right)$ to yield compound 9a (ester $\left.\gamma\right)(222 \mathrm{mg}, 62 \%$ over two steps) as a colorless foam. ${ }^{1} \mathrm{H}$ NMR (400 MHz, Methanol-d4) $\delta 7.72(\mathrm{~d}, J=7.9 \mathrm{~Hz}, 2 \mathrm{H}), 7.37$ (d, J=7.9 Hz, 2H), $5.97(\mathrm{~d}, J=3.4 \mathrm{~Hz}, 1 \mathrm{H}), 3.97-3.82(\mathrm{~m}, 4 \mathrm{H}), 3.77-3.62(\mathrm{~m}, 4 \mathrm{H}), 3.27-3.20(\mathrm{~m}, 3 \mathrm{H}), 2.42$ (s, 3H), 1.29 (d, $J=7.2 \mathrm{~Hz}, 3 \mathrm{H})$. LCMS (m/z) 491.7 (M-1); RT (Method 2, std LCMS method), $0.79 \mathrm{~min}$.

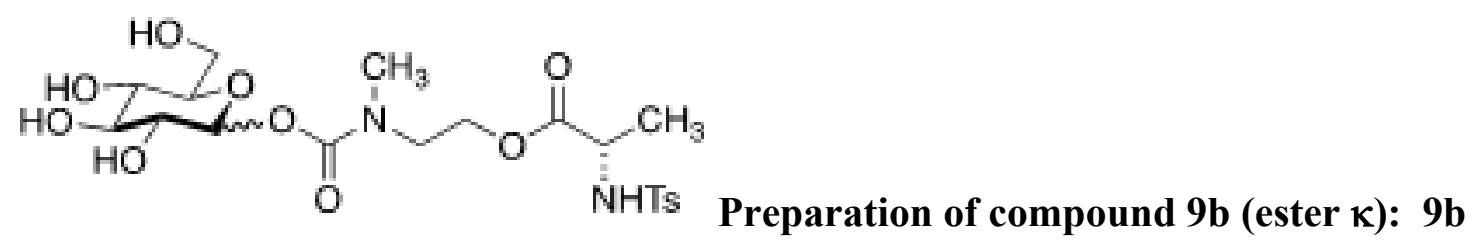

(ester $\mathbf{\kappa}$ ) was prepared by using the reaction conditions described above and the corresponding acid $7 \mathbf{b}$ (475 $\mathrm{mg}, 0.73 \mathrm{mmol}, 1$ equiv). The crude material after the final removal of all the chloroacetyl groups was purified by Biotage flash chromatography (gradient elution, 0 to $25 \% \mathrm{MeOH}$ in $\mathrm{CH}_{2} \mathrm{Cl}_{2}$ ) to yield compound $9 \mathbf{b}$ (ester $\boldsymbol{\kappa}$ ) (225 mg, 50\% over two steps) as a colorless gel. 'H NMR (400 MHz, Methanol-d4) $\delta 7.72(\mathrm{~d}, J=8.1 \mathrm{~Hz}, 2 \mathrm{H}), 7.37(\mathrm{~d}, J=8.0 \mathrm{~Hz}$, 2H), $5.99(\mathrm{~d}, J=3.3 \mathrm{~Hz}, 1 \mathrm{H}), 4.14-3.91(\mathrm{~m}, 3 \mathrm{H}), 3.78-3.66(\mathrm{~m}, 3 \mathrm{H}), 3.64-3.41(\mathrm{~m}, 5 \mathrm{H})$, $2.43(\mathrm{~s}, 3 \mathrm{H}), 1.37$ (d, $J=6.4 \mathrm{~Hz}, 3 \mathrm{H}), 1.28$ (d, $J=6.8 \mathrm{~Hz}, 3 \mathrm{H})$. LCMS (m/z) 505.8 (M-1); RT (Method 2, std LCMS method), $0.80 \mathrm{~min}$.

\section{References}

1. Y. Zhu, J. Ralph, Tetrahedron Letters, 2011, 52, 3729-3731.

\section{IH NMR spectra:}



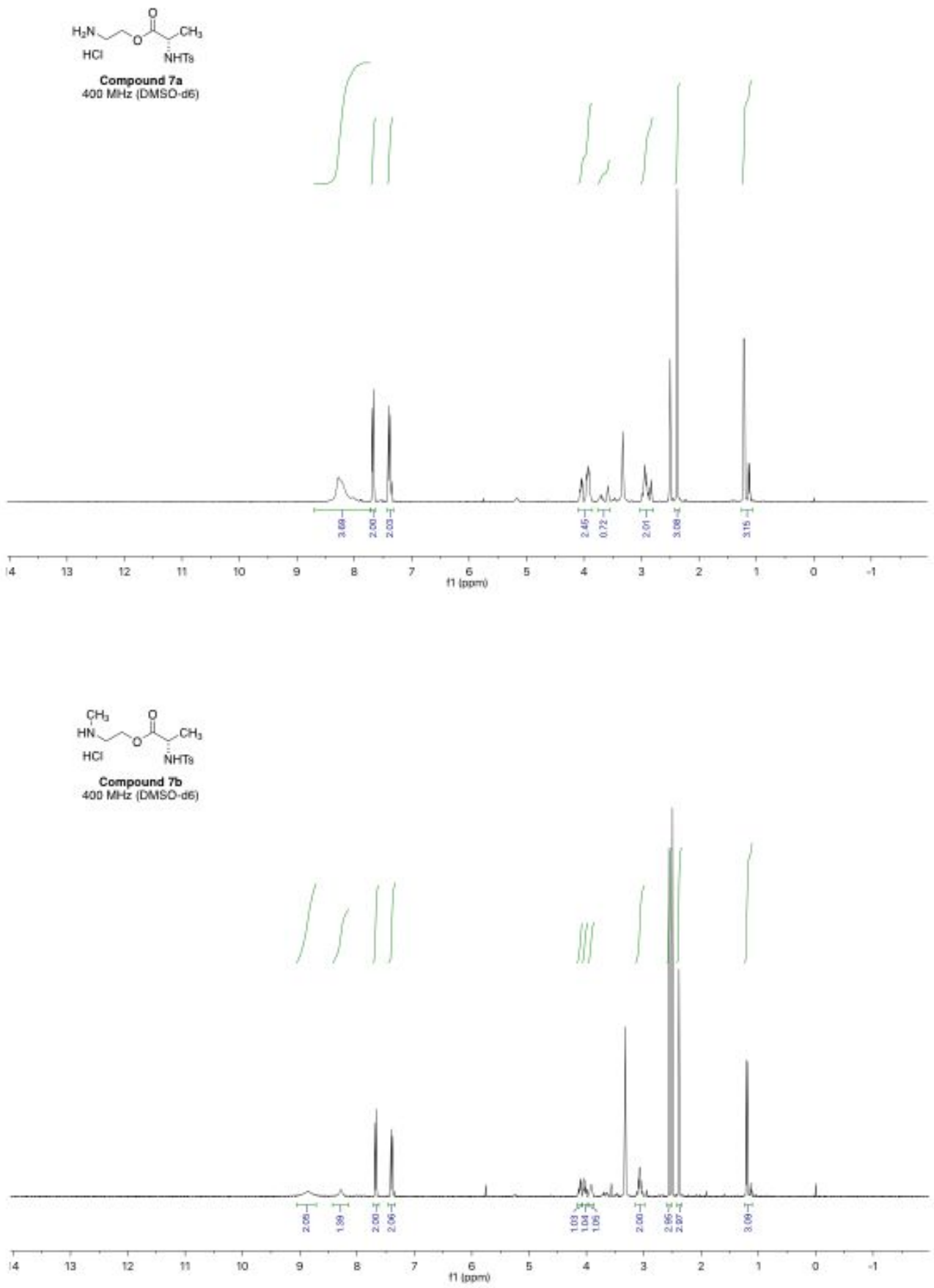

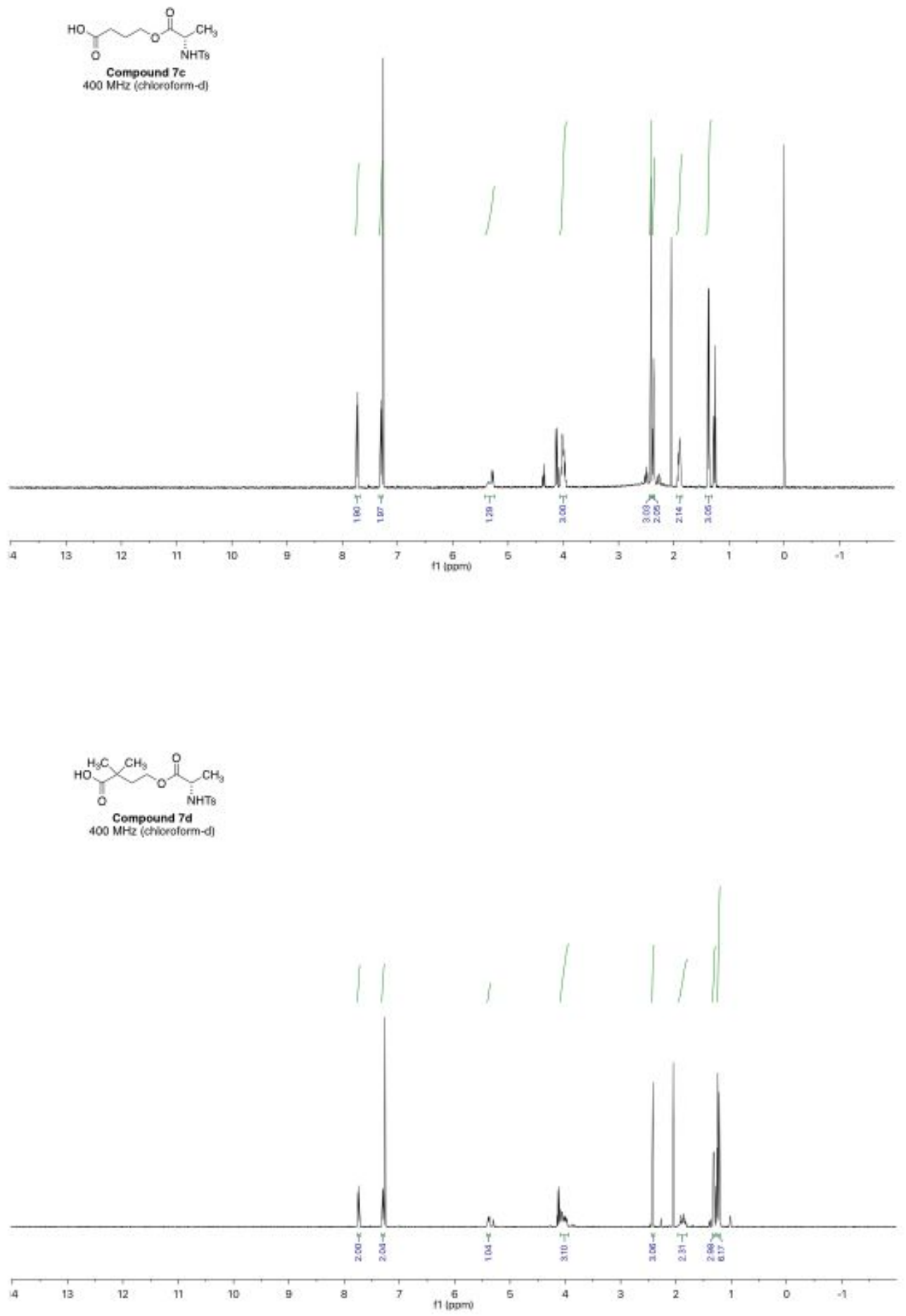

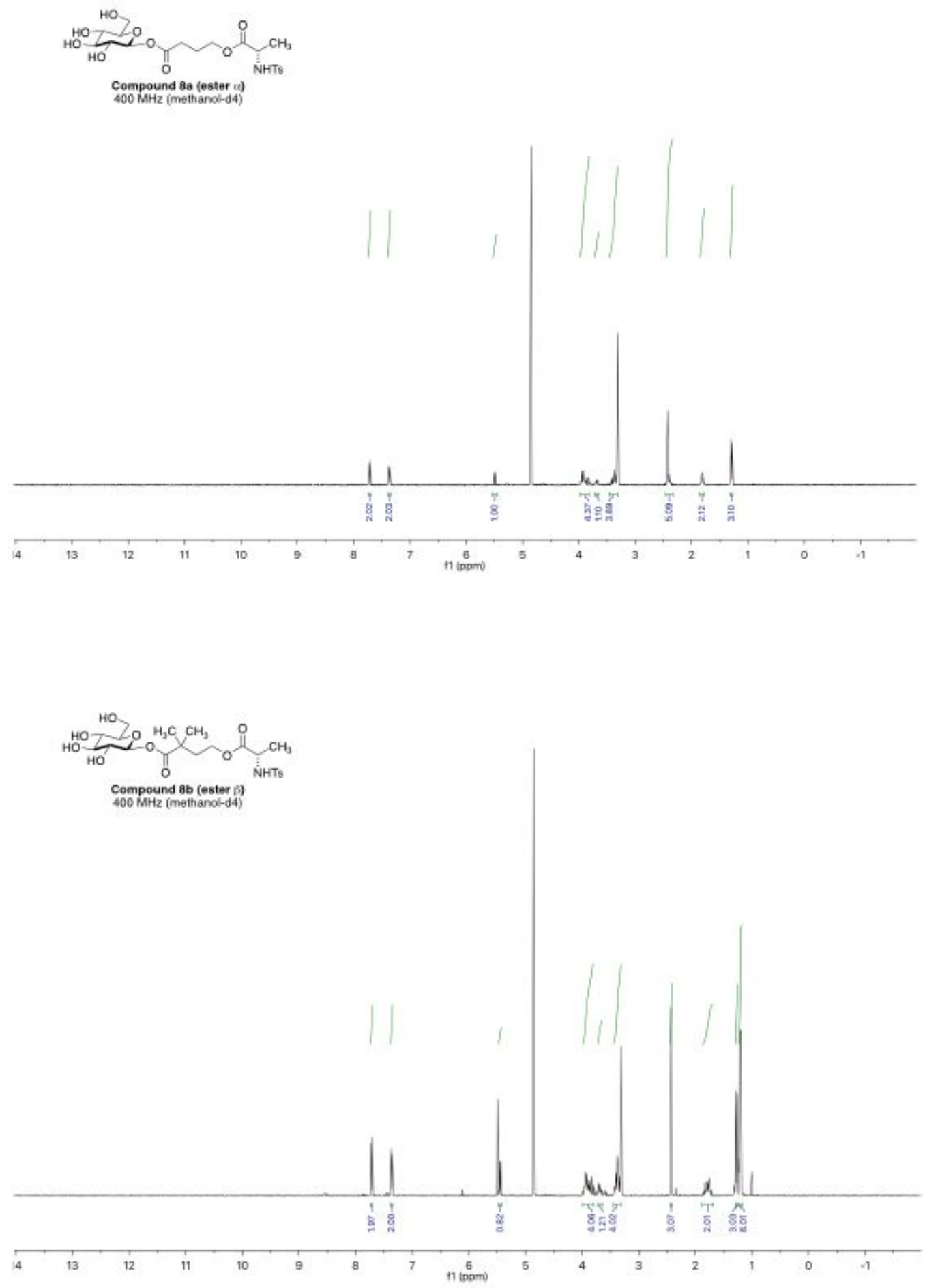

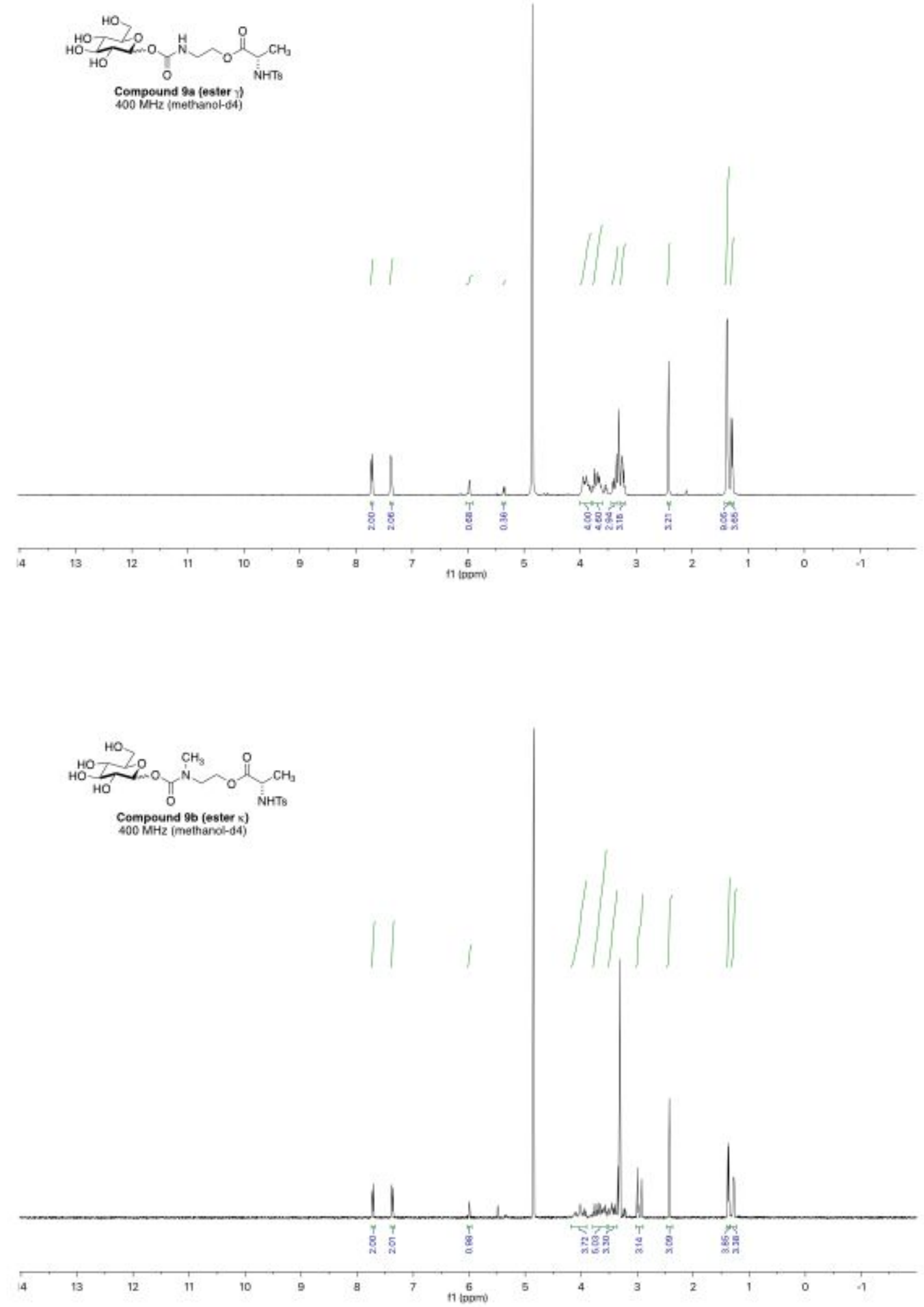